PhD (Pedagogy), Senior Lecturer at English Philology Department, Kryvyi Rih State Pedagogical University, 54 Gagarina Ave, 50086 Kryvyi Rih, Ukraine, vimaiv@ukr.net

\title{
THE USE OF TRAINING COURSES IN THE DEVELOPMENT OF FUTURE ENGLISH TEACHERS' FOREIGN LANGUAGE COMMUNICATIVE COMPETENCE
}

The article is focused on the presentation of the content and the approbation results of professional growth training courses. They are aimed at developing separate components of future English teachers' foreign language communicative competence. The experiment results testify the efficiency of professional growth training courses for prospective foreign language teachers' professional training optimization. The data of post-experimental testing show the increasing number of students with a high and intermediate level of foreign language communicative competence.

Key words: foreign language communicative competence; future English teachers' professional training; interactive techniques; professional growth training courses; professionally significant qualities.

https://doi.org/10.28925/2078-1687.2018.4.6470

Introduction. Nowadays transformations in the system of education are imposing new requirements for pedagogical education in general and pre-service English teachers' training in particular. According to the National Standard of Basic and Complete Secondary Education (2011) the priority is given not only to the acquisition of deep general scientific and professional knowledge, but also to the improvement of the skills demanded for independent study and independent professional growth, to the development of a higher level of creative cognitive activity, the ability to demonstrate an original approach to resolve issues, and the ability to work in a team-based cooperation and co-creation. Thus, in this research attention is focused on developing future English teachers' foreign language communicative competence as a component of their professional education.

The research works on the subject touch upon the issues of competence approach in professional education (Zimnjaja, 2003; Karpova, 2004; Hutorskoy, 2003), foreign language education (Tarnopolskyi, 2005; Shhukin, 2004), theory (Stavycjka, 2013) and practice of students' foreign language communicative competence development (Kostjukova, 2011; Skljarenko, 2010; Chorna, 2013; Hymes, 1971). A number of works (Borisko, 2010;
Roman, 2012) concern the issue of professionally oriented foreign language communicative competence as a particular level of communicative competence development that is relevant to foreign language teachers.

Accordingly, the topicality of this research is determined by the demand of the society for highly qualified English teachers, the necessity for the development of prospective English teachers' communicative competence and the imperfection of the methodological support for its development.

The aim of this article is to present the content of professional growth training courses and to confirm their effectiveness for prospective English teachers' professional education. According to the stated goal the following tasks are formulated: 1) to describe the content and the components of foreign language communicative competence of future English teachers; 2) to elaborate the content of professional growth training courses, focusing on the development of separate components of future English teachers' foreign language communicative competence; 3) to prove experimentally the effectiveness of the suggested course.

The research was carried out at Kryvyi Rih State Pedagogical University in 2016-2017 academic year involving 80 first and second year undergraduate students of the Faculty of Foreign Languages, majoring in the English Language and Literature 
who were divided into four groups - experimental group 1 (EG 1) - 20 students, experimental group 2 (EG 2) - 20 students, control group 1 (CG 1) 20 students, control group 2 (CG 2) - 20 students. The CG 1 and CG 2 were taught only within the subject «Practical course of English», while the EG 1 and EG 2 completed the suggested courses. The empirical research included the following stages:

1. The implementation of the pre-experimental testing to define the initial level of undergraduate students' foreign language communicative competence;

2. Empirical training according to the program of the course suggested;

3. The implementation of the post-experimental testing to define the final level of undergraduate students' foreign language communicative competence.

In order to collect data for the research the following methods were applied: theoretical (analysis, comparison, generalization, systematization of pedagogical, psychological and methodological sources to study the problem of the implementation of specialized training courses as a means of developing future foreign language teachers' communicative competence), empirical (testing, questionnaires), statistical (mathematical processing of obtained data).

According to modern tendencies in education, professional training involves developing professional competence. In State Educational Standard (2011) «competence» is defined as «an integrated ability of the person, which consists of knowledge, skills, experience, values, and attitudes, is acquired in the process of learning and can be implemented into practice». The competencebased approach in foreign language education modernization in higher pedagogical educational establishments lies in the development of students' foreign language communicative competence. The concept of communicative competence was introduced by D. Hymes (1971), who interpreted it as the ability to use grammatical competence in a variety of communicative situations.

We express our solidarity with Borisko (2010) and Roman (2012) who speak about professionally oriented foreign language communicative competence and define it as «a particular level of development of communicative competence that is relevant to foreign language teachers» (Borisko, 2010 , p. 4). Following them, we believe that future English teachers' foreign language communicative competence has a double nature and involves the development of such characteristic features as the willingness to participate in foreign language intercultural communication and the ability to teach students a foreign language as a means of communication in the dialogue of cultures. In this respect, we consider future English teachers' foreign language communicative competence as the cumulative characteristics of knowledge and skills that are internalised by the personality and are manifested in the willingness to participate in foreign language intercultural communication and the ability to teach English as an academic subject.

Didactic and methodological research works (Bakum, 2012; Borisko, 2010; Gal'skova \& Gez, 2006; Bighych, Borysko \& Borecjka, 2010; Lewis, 1985; Maiier, 2017), our own experience of studying the specifics of prospective English teachers' professional training give grounds to determine the component composition of future teachers' foreign language communicative competence: linguistic competence (knowledge of linguistic means and the rules of their usage; speech competence (listening, speaking, reading and writing), communicative competence (ability to communicate); sociocultural competence (knowledge of social and cultural context); sociolinguistic competence (the ability to select language forms, use them and transform in accordance with the context and awareness of the links between the language (languages) and social phenomena); pragmatic competence (the ability to use language effectively in a contextually appropriate fashion). Taking into consideration the component structure of foreign language communicative competence, we singled out a minimum of professionally significant knowledge and skills which is necessary for professionally oriented communicative competence development. It includes:

- communicative skills (ability to initiate a dialogue, to respond to the remark of the interlocutor, to keep the conversation going, to encourage the interlocutor to respond the statement);

- lexical and grammatical skills;

- the demonstration of the creative approach to the task fulfillment;

- knowledge about the culture of the country which language is studied.

The pre-experimental testing was aimed at defining the initial level of undergraduate students' foreign language communicative competence. Students were assessed according to the degree of development of the mentioned-above skills in the process of doing the following activities:

1. Solving a problem. 
2. Opinion sharing.

3. Work in small groups with a piece of authentic material.

To assess students' results, three levels of foreign language communicative competence development were singled out: high, intermediate, low.

The low level of foreign language communicative competence development is characterized by the insufficient level of communicative skills (inability to engage in a dialogue, to converse, to argue), limited vocabulary and poor knowledge of grammatical structures, formal approach to the task fulfillment, almost complete absence of sociocultural knowledge, inability to cover the topic.

The intermediate level of foreign language communicative competence development is characterized by the ability to hold a conversation (to enter into a dialogue, to defend one's position), to use vocabulary in accordance with the situation, but with certain restrictions, to use grammatical structures correctly, to demonstrate independent ways of performing tasks, but relying on previously learned material, to cover the topic sufficiently enough with the use of sociocultural knowledge.

The high level of foreign language communicative competence development is characterized by the advanced level of communicative skills development, extended vocabulary and strong knowledge of grammar, which is demonstrated in the ability to express one's thoughts freely in a foreign language, in the creative approach to the fulfillment of the assignment, in the full scope of the subject coverage, in the use of socio-cultural knowledge in accordance with the situation.

The results of the pre-experimental testing testify to the fact that only $5.9 \%$ and $4.9 \%$ of students in the experimental groups (EG 1, EG 2) demonstrated the high level of foreign language communicative competence. The results of the survey show that $83 \%$ of the respondents questioned see the reason for it in the insufficient use of intensive training via interactive teaching techniques of work in pairs, small groups, which involve various forms of interaction; in the absence of specific training courses, aimed at developing professionally significant qualities of future foreign language teachers; in the lack of teaching materials and methodological support for their development.

Thus, the aim of the specialized professional growth training courses is to develop professionally significant qualities of prospective English teachers' foreign language communicative competence.

According to the definition given by $\mathrm{B}$. BimBad (2003), «training» is «intensive learning with practical orientation» (p. 291). Unlike lectures, seminars, workshops, training courses are focused on developing all the necessary skills and creating conditions for the development of personal qualities to perform professional activity.

Taking into consideration the component composition of the foreign language communicative competence, the program of professional growth training courses has been worked out and presented in our methodological recommendations (Revenko, 2016).

The program included the following components:

- the training course on the development of sociocultural competence;

- the training course on the improvement of conversational skills;

- the training course on the acquisition of creative abilities;

- the training course on the obtainment of future English teachers' qualifications, in particular, interest in future profession.

We developed a set of activities for each component of the training courses by using our own experience in foreign language teacher education and well-known national and foreign methodologists' best practice guidelines. As the role of intensive technologies, which involve verbal interaction between a teacher and learners, is fundamental in the educational process, the system of specialized professional growth training courses was based on interactive techniques of work in pairs, small groups that provide various types of interaction within the systems «student - student», «teacher - student(s)», «student mini-group», «student - class», which contribute to the development of students' cognitive activity and initiative during their learning, the formation of cooperation and communicative skills, and interpersonal communication.

The training course on the development of sociocultural competence was implemented at the second year of Bachelor's degree program while studying the educational theme «Food»/ «Meals». Its aim was to improve future teachers' communicative skills, to acquire the knowledge about the culture of different countries, to implement cooperation and co-creation in the systems «student - student», «teacher-student(s)».

The training course on the obtainment of prospective teachers' qualifications, in particular, the development of an interest in future profession, is aimed at allowing the students to analyze their future professional activity, to get acquainted with its specifics and to gain a better understanding of it. 
Upon completion of the empirical training the post-experimental testing was carried out. We assessed the changes in the levels of future English teachers' foreign language communicative competencebased on the results of pre-experimental and post-experimental testing by the same criteria. The data of post-experimental testing show much higher values of foreign language communicative competence in groups EG 1, EG 2 in comparison with the ones of CG 1, CG 2 (see Table 1).

Table 1

\section{A Comparative Table of the Dynamics in the Development of Foreign Language Communicative Competence after the Empirical Training}

\begin{tabular}{|c|c|c|c|c|c|c|c|c|}
\hline \multirow{3}{*}{$\begin{array}{l}\text { Levels of } \\
\text { foreign } \\
\text { language } \\
\text { communicative } \\
\text { competence }\end{array}$} & \multicolumn{4}{|c|}{ Control groups } & \multicolumn{4}{|c|}{ Experimental groups } \\
\hline & \multicolumn{2}{|c|}{ CG 1} & \multicolumn{2}{|c|}{ CG 2} & \multicolumn{2}{|c|}{ EG 1} & \multicolumn{2}{|c|}{ EG 2} \\
\hline & a & $\mathrm{b}$ & $\mathrm{a}$ & $b$ & a & $\mathrm{b}$ & a & $\mathrm{b}$ \\
\hline High & 5,8 & 4,2 & 5,4 & 4,7 & 5,9 & 12,6 & 4,9 & 13,9 \\
\hline Intermediate & 32,2 & 36 & 34,4 & 32 & 39 & 61,3 & 41 & 63,6 \\
\hline Low & 62 & 59,8 & 60,2 & 63,3 & 55,1 & 26,1 & 54,1 & 22,5 \\
\hline
\end{tabular}

Footnote: $\mathrm{a}$ - pre-experimental level of foreign language communicative competence, $\mathrm{b}$ - post-experimental level of foreign language communicative competence.

The data in Table 1 testify to the dynamics of the level of foreign language communicative competence of students of the experimental groups from low to higher levels. Before the beginning of the empirical training the high level of foreign language communicative competence was demonstrated by $5.9 \%, 4.9 \%$ of the students of the experimental groups, whereas after the empirical research it was demonstrated by $12.6 \%$, $13.9 \%$ of the students of the experimental groups. The intermediate level increased from 39\%, 41\% to $61.3 \%, 63.6 \%$ respectively, while the low level of foreign language communication competence decreased from $55.1 \%, 54.1 \%$ to $26.1 \%$, and $22.5 \%$ respectively. There were no significant changes in this indicator in the control groups. The effectiveness of the implementation of professional growth training courses for the development of future foreign language teachers' foreign language communicative competence has been proved.

Conclusion. Thus, pursuant to the objectives set the content of the professional growth training courses was developed. The structure of the courses and the range of activities enabled the students not only to check their knowledge of the theme that had been studied, to expand their vocabulary and to develop their communicative skills, but also to study the cultural background of the English-speaking countries, to participate in the dialogue of cultures, to develop cognitive activity and initiative during their studies, to develop cooperation and interpersonal communication skills. The proposed tasks contributed to the development of students' communicative abilities, interest in the future profession, the obtainment of professional qualifications, the implementation of cooperation and co-creation in the systems «student - student», «teacher - student(s)».

After the completion of the empirical training program, the number of students who demonstrated high and intermediate level of foreign language communicative competence has significantly increased.

Prospects for further research are seen in working out special training courses to develop other components of future English teachers' professional competence.

\section{References}

Bakum, Z., \& Paljchykova, O. (2012). Kros-kuljturnyj pidkhid u vykladanni inozemnoji movy studentamfilologham. [The cross-cultural approach in teaching foreign language to students of philology]. Teoretychna i dydaktychna filologhija, 13, 3-7 (ukr).

Bighych, O. B. (Ed.) (2010). Metodyka formuvannja mizhkuljturnoji inshomovnoji komunikatyvnoji kompetenciji [Methodology of formation of intercultural communication communication competence]. Kyiv, Ukraine: Lenvit (ukr). 
Borisko, N. F. (2010). Formirovanie professional'no orientirovannoj kommunikativnoj kompetencii na prakticheskih zanjatijah po inostrannomu jazyku ili skol'ko metodiki nuzhno budushhemu uchitelju [The development of professionally oriented foreign language communicative competence in the English language course or how much methodology a future teacher needs]. Inozemni movy, 2, 310 (rus).

Gal'skova, N. D., \& Gez, N. I. (2006). Teorija obuchenija inostrannym jazykam. Lingvodidaktika $i$ metodika[Theory of teaching foreign languages. Linguodidactics and methodology]. Moscow, Russia: Akademija (rus).

Derzhavnyj standart bazovoji $i$ povnoji zaghaljnoji serednjoji osvity [National standard of basic and complete general secondary education]. Retrieved from http://zakon2.rada.gov.ua/laws/show/13922011-\%D0\%BF (ukr).

Zimnjaja, I. A. (2003). Kljuchevye kompetencii - novaja paradigma rezul'tata obrazovanija [Key competencies as the new paradigm of the result of education]. Vysshee obrazovanie segodnja, 5, 3442 (rus).

Karpova, L. Gh. (2004). Formuvannja profesijnoji kompetentnosti vchytelja zaghaljnoosvitnjoji shkoly [Forming of the Professional Competence of a Secondary School Teacher]. Extended abstract of candidate's thesis. Kharkiv, Ukraine (ukr).

Kostjukova, T. A., \& Morozova, A. L. (2011). Razvitie inojazychnoj kommunikativnoj kompetentnosti studentov nejazykovyh vuzov [Development of foreign communicative competence of students of nonlinguistic universities]. Tomsk, Russia: TPU (rus).

Bim-Bad, B. M. (Ed.) (2003). Pedagogicheskij jenciklopedicheskij slovar' [Pedagogical Encyclopedic Dictionary]. Moscow, Russia: Bolshaja rossijskaja jenciklopedija (rus).

Revenko, V. V. (2016). Zastosuvannja interaktyvnykh tekhnologhij navchannja u procesi profesijnoji pidghotovky majbutnikh uchyteliv inozemnykh mov: metodychni rekomendaciji [Implementation of interactive learning technologies in the process of future foreign language teachers' training: methodical recommendations]. Kryvyj Righ, Ukraine: KRSPU (ukr).

Roman, S. V. (2012). Profesijno orijentovana inshomovna komunikatyvna kompetentnistj majbutnikh uchyteliv inozemnoji movy jak predmet formuvannja $\mathrm{v}$ kursi praktyky usnogho ta pysemnogho movlennja. [Pre-service Foreign Language Teachers' Professionally Oriented Foreign Language Communicative Competence as the Goal for Development in the English Language Course]. Inozemni movy, 2, 39-45 (ukr).

Skljarenko, N. K. (2010). Metodyka formuvannja inshomovnoji ghramatychnoji kompetenciji v uchniv zaghaljnoosvitnikh navchaljnykh zakladiv [Foreign Grammatical Competence Formation]. Inozemni movy, 4, 15-25 (ukr).

Stavycjka, I. V. (2013). Inshomovna kompetentnistj: misce definiciji u terminologhichnomu poli suchasnykh naukovykh sudzhenj [Foreign language competence: the place of definition in terminology field of modern scientific statements]. Pedaghoghichni nauky: teorija, istorija, innovacijni tekhnologhiji, 4 (30), 280-286 (ukr).

Tarnopoljsjkyj, O. (2006). Metodyka navchannja inshomovnoji movlennjevoji dijaljnosti u vyshhomu movnomu zakladi osvity [Methods of teaching foreign language communication language in higher education institution]. Kyiv, Ukraine: INKOS (ukr).

Hutorskoj, A. (2003). Kljuchevye kompetencii kak komponent lichnostno-orientirovannogo obrazovanija [Key competencies as a component of student-centered education]. Narodnoe obrazovanie, 2, 58-64 (rus).

Chorna, O.O.(2013). Osoblyvostita praktykaformuvannjainshomovnoji komunikatyvnoji kompetentnosti studentiv tekhnichnykh specialjnostej [Peculiarities and Practice of the Formation of Non-Philological Students' Foreign Communicative Competence]. Vikladannya mov u vishih navchalnih zakladah osviti na suchasnomu etapi, 22, 230-237 (ukr).

Shchukin, A. N. (2004). Obuchenie inostrannym jazykam. Teorija i praktika [Teaching foreign languages. Theory and practice]. Moscow, Russia: Filomatis (rus).

Hymes, D. (1971). On Communicative Competence. Philadelphia, USA: University of Pennsylvania Press (eng).

Lewis, M., \& Hill, J. (1985). Practical Techniques: For Language Teaching. Hove, Great Britain: Language Teaching (eng).

Maiier, N. (2017). The methodological training of future university teachers to implement intercultural foreign language education: competency-based approach. Advanced Education, 8, 4-9. DOI: https:// doi.org/10.20535/2410-8286.101358 (eng). 


\section{Література}

Бакум 3., Пальчикова О. Крос-культурний підхід у викладанні іноземної мови студентамфілологам. Теоретична і дидактична філологія. 2012. № 13. С. 3-7.

Бігич О. Б. (Ред.). Методика формування міжкультурної іншомовної комунікативної компетенції: курс лекцій. Київ: Ленвіт, 2010. 332 с.

БорискоН.Ф. Формирование профессионально ориентированной коммуникативной компетенции на практических занятиях по иностранному языку или Сколько методики нужно будущему учителю? Іноземні мови. 2010. № 2. С. 3-10.

Гальскова Н. Д., Гез Н. И. Теория обучения иностранным языкам. Лингводидактика и методика: учебное пособие. Москва: Академия, 2006. 336 с.

Державний стандарт базової і повної загальної середньої освіти. URL: http://osvita.ua/legislation/ Ser_osv/28030/ (дата звернення: 28.08.2018).

Зимняя И. А. Ключевые компетенции - новая парадигма результата образования. Высшее образование сегодня. 2003. № 5. С. 34-42.

Карпова Л. Г. Формування професійної компетентності вчителя загальноосвітньої школи: автореф. дис... канд. пед. наук: спец.13.00.04 «Теорія та методика професійної освіти». Харків, 2004. 20 с.

Костюкова Т. А., Морозова А. Л. Развитие иноязычной коммуникативной компетентности студентов неязыковых вузов: монография. Томск: ТПУ, 2011. 119 с.

Педагогический энциклопедический словарь / сост. Бим-Бад Б. М. Москва: Большая российская энциклопедия, 2003. 528 с.

Ревенко В. В. Застосування інтерактивних технологій навчання у процесі професійної підготовки майбутніх учителів іноземних мов: методичні рекомендації. Кривий Ріг: КДПУ, 2016. 45 с.

Роман С. В. Професійно орієнтована іншомовна комунікативна компетентність майбутніх учителів іноземної мови як предмет формування в курсі практики усного та писемного мовлення. Іноземні мови. 2012. № 2. С. 39-45.

Скляренко Н. К. Методика формування іншомовної граматичної компетенції в учнів загальноосвітніх навчальних закладів. Іноземні мови. 2010. № 4. С. 15-25.

Ставицька I. В. Іншомовна компетентність: місце дефініції у термінологічному полі сучасних наукових суджень. Педагогічні науки: теорія, історія, інноваційні технології. 2013. № 4 (30). С. 280-286.

Тарнопольський О. Б. Методика навчання іншомовної мовленнєвої діяльності у вищому мовному закладі освіти: посібник. Київ: Інкос, 2006. 248 с.

Хуторской А. Ключевые компетенции как компонент личностно-ориентированного образования. Народное образование. 2003. № 2. С. 58-64.

Чорна О. О. Особливості та практика формування іншомовної комунікативної компетентності студентів технічних спеціальностей). Викладання мов у вищих навчальних закладах освіти на сучасному етапі. 2013. Вип. 22. С. 230-237.

Щукин А. Н. Обучение иностранным языкам. Теория и практика. Москва: Филоматис, 2004. 416 с. Hymes D. On Communicative Competence. Philadelphia: University of Pennsylvania Press, 1971. 174 p. Lewis M. Practical Techniques: For Language Teaching. Hove: Language Teaching, 1985. 133 p.

Maiier N. The methodological training of future university teachers to implement intercultural foreign language education: competency-based approach. Advanced Education. 2017. № 8. C. 4-9. DOI: https:// doi.org/10.20535/2410-8286.101358.

\section{ИСПОЛЬЗОВАНИЕ ТРЕНИНГОВ В ФОРМИРОВАНИИ ИНОЯЗЫЧНОЙ КОММУНИКАТИВНОЙ КОМПЕТЕНТНОСТИ БУДУЩИХ УЧИТЕЛЕЙ АНГЛИЙСКОГО ЯЗЫКА}

Ревенко Виктория, кандидат педагогических наук, старший преподаватель кафедры английской филологии, Криворожский государственный педагогический университет, пр. Гагарина, 54, 50086 Кривой Рог, Украина, vimaiv@ukr.net

Статья посвящена внедрению интенсивных технологий, в частности тренингов, в процесс формирования иноязычной коммуникативной компетентности будущих педагогов. Целью статьи является подтверждение эффективности использования тренингов профессионального развитияв процессе формирования отдельных показателей иноязычной коммуникативной компетентности будущих учителей английского языка. Доказана эффективность использования тренингов как средства формирования отдельных показателей иноязычной коммуникативной компетентности 
будущих учителей английского языка. Диагностика уровня сформированности указанных показателей до и после экспериментального обучения свидетельствует о росте количества студентов с высоким и средним уровнем иноязычной коммуникативной компетентности.

Ключевые слова: иноязычная коммуникативная компетентность; интерактивные приемь; профессиональная подготовка будущего учителя иностранных языков; профессионально значимые качества; тренинг.

\title{
ЗАСТОСУВАННЯ ТРЕНІНГІВ У ФОРМУВАННІ ІНШОМОВНОЇ КОМУНІКАТИВНОЇ КОМПЕТЕНТНОСТI МАЙБУТНІХ УЧИТЕЛІВ АНГЛІЙСЬКОЇ МОВИ
}

\begin{abstract}
Ревенко Вікторія, кандидат педагогічних наук, старший викладач кафедри англійської філології, Криворізький державний педагогічний університет, пр. Гагаріна, 54, 50086 Кривий Ріг, Україна, vimaiv@ukr.net
\end{abstract}

Соціально-економічні зміни в сучасній Украйні, зокрема ї інтеграція в європейське співтовариство, зумовлюють необхідність ребормування системи вищої освіти, що передовсім спрямовується на більш якісну професійну підготовку майбутнього вчителя іноземних мов. Саме тому ия стаття присвячена упровадженню інтенсивних технологій, зокрема тренінгів, у проиес бормування іншомовної комунікативної компетентності майбутніх педагогів у межах вивчення дисципліни «Практичний курс англійської мови». Метою статті є підтвердження ефективності використання тренінгів професійного розвитку в процесі формування окремих показників іншомовної комунікативної компетентності майбутніх учителів англійської мови.

У дослідженні іншомовну комунікативну компетентність майбутнього вчителя іноземних мов розглянуто як сукупну характеристику знань, умінь та навичок, що інтеріоризовані особистістю та проявляються в готовності до участі в іншомовній міжкультурній комунікацій, здатності вивчати іноземну мову як предмет навчання інших иієї мови.

У процесі дослідження упроваджувалася програма тренінгів пробесійного розвитку, щзо передбачала: тренінг із формування полікультурного компоненту іншомовної комунікативної компетентності; тренінг із формування персонального компоненту професійної компетентності, зокрема формування пробесійних якостей майбутнього педагога; тренінг із розвитку комунікативних умінь; тренінг із розвитку творчих здібностей. В основу тренінгів покладено інтерактивні прийоми, що передбачали різні види інтерактивної взаємодії в системах «студент - студент», «викладач - студент(и)», «студент - мінігрупа», «студент -академгрупа». Доведено ефективність використання тренінгів як засобу формування окремих показників іншомовноі комунікативної компетентності майбутніх учителів англійської мови. Діагностика рівня сформованості означених показників до та після експериментального навчання свідчить про зростання кількості студентів з високим та середнім рівнем іншомовної комунікативної компетентності.

Ключові слова: інтерактивні прийоми; іншомовна комунікативна компетентність; професійна підготовка майбутнього вчителя іноземних мов; професійно значущі якості; тренінг. 